\title{
Closing the door on illicit tobacco trade, opens the way to better tobacco control
}

\author{
Vinayak Prasad, ${ }^{1}$ Ulrike Schwerdtfeger, ${ }^{2}$ Fatimah El-Awa, ${ }^{3}$ Douglas Bettcher ${ }^{4}$ and Vera da Costa e Silva ${ }^{5}$
}

This year we are celebrating with the world the 10th anniversary of the entry into force of the World Health Organization Framework Convention on Tobacco Control (WHO FCTC). Parties to the WHO FCTC have come a long way in tobacco control since the negotiations of the Convention started; nonetheless there are still major challenges facing tobacco control, one of which is illicit tobacco trade that, unless comprehensively addressed now, can compromise the gains of tobacco control.

In response to the problem of illicit tobacco trade and its repercussions on public health, Parties to the WHO FCTC negotiated the Protocol to Eliminate Illicit Trade in Tobacco Products, which was adopted on 12 November 2012 at the fifth session of the Conference of the Parties (COP) to the WHO FCTC in Seoul, Republic of Korea. It is the first protocol to the WHO FCTC.

Illicit tobacco trade is a global problem and countries of the WHO Eastern Mediterranean Region (EMR) are suffering equally from its health and economic consequences. They have been exposed to its negative impacts for years, as documented by internal documents of the tobacco industry (1). Due to the growing population of tobacco users and the transitional political conditions in a significant number of countries, the EMR provides tobacco companies with a unique market to target their product and expand their illicit trade (2).
Literature on the subject shows beyond doubt that the industry has been using various routes in the Region to smuggle its products into, out of and within the Region (3).

The impact of illicit tobacco trade on tobacco control policies and gains should not be underestimated. It leads to a growth in consumption of tobacco products and hence an increase in the associated disease burden and death (4). Illicit tobacco products are not subject to taxation, which means that they are cheaper, unregulated products that are easily available and accessible, especially to youth and the poor. In addition, these illegal products do not meet the regulatory requirements for health warnings and other regulations for packaging and labelling of tobacco products. Therefore illicit tobacco trade is a direct and significant threat to tobacco control policies and it compromises advances that have been made in tackling tobacco use.

In the EMR, illicit tobacco trade is not limited to cigarette products; another area of concern is the smuggling of waterpipe tobacco. One indication of the extent of illegal trade is the number of seizures made in the countries in the Region. For 2013, member administrations of the World Customs Organization reported through the Customs Enforcement Network (a database of customs seizures and offences worldwide), a total of 182 seizures of waterpipe tobacco, which constituted a considerable increase from 42 seizures in 2012 (5). A recent report in the news also suggests that chewing tobacco products are part of the illicit tobacco trade activities in the Region (6).

The use of tobacco is escalating in the Region including the use of both waterpipe and smokeless tobacco (7). Any increase in illicit trade in these tobacco products will lower their cost and therefore increase their availability, especially to the younger generation who are regular users of waterpipe and chewed tobacco (8).

Despite the compelling evidence on the presence of illicit tobacco trade in the Region, transparent, regular and reliable estimates on its size in each country are not available, and many regional Member States do not have any estimates. While this is in part due to the illegal nature of the activities and hence the difficulty in obtaining data, some studies have provided useful information on the illicit tobacco trade. For example, a study conducted by the Tobacco Control and Prevention Research Centre in the Islamic Republic of Iran found that $21 \%$ of all cigarettes on the market in Tehran in 2009 were illicit (9). According to Euromonitor data, of total cigarette consumption, the share of the illicit cigarettes market increased from $12 \%$ in 2008 to $28 \%$ in 2013 in Tunisia, peaked at 24\% in Egypt in 2012 and was more than $20 \%$ in the United Arab Emirates in 2013 (10). 
It is encouraging that countries of the Region were actively engaged in the negotiations of the WHO FCTC Protocol to Eliminate Illicit Trade in Tobacco Products. The Protocol has been open for ratification, acceptance, approval, formal confirmation or accession by all Parties to the WHO FCTC since 10 January 2013. While eight EMR Member States of the Region have signed the Protocol, none has yet ratified it in order to become a Party. The adoption of the Protocol provides a strong impetus to generate a concerted global/regional response to counter the increasing threat of the illicit tobacco trade.

If we are to eliminate the illicit trade in tobacco, Member States of the Region need to adopt enforceable measures to control the supply chain as well as international cooperative measures, including information sharing and cooperation in the investigation and prosecution of offences, which are all at the heart of the Protocol.

By becoming Parties to the Protocol, Member States of the EMR will strengthen their capability to fight the illicit trade and will support international cooperation for capacity building and information sharing. Ratification, acceptance, approval or accession to the Protocol is the starting point.

\section{References}

1. Coveting Iran: The infiltration and exploitation of Iran by global cigarette companies (http://applications.emro.who.int/dsaf/ EMRPUB_2001_EN_767.pdf?ua=1, accessed 23 March 2015).

2. Maziak W, Nakkash R, Bahelah R, Husseini A, Fanous N, Eissenberg T. Tobacco in the Arab World: old and new epidemics amidst policy paralysis. Health+ Policy Plan. 2014 Sep;29(6):784-94. PMID:23958628 (http://heapol.oxfordjournals.org/content/early/2013/08/19/heapol.czt055.full. html?papetoc\#ref-39, accessed 23 March 2015).

3. The cigarette "transit" road to the Islamic Republic of Iran and Iraq. Illicit tobacco trade in the Middle East.Geneva:World Health Organization; 2008, second edition (WHO-EM/ TFI/011/E/G; http://applications.emro.who.int/dsaf/dsa908. pdf, accessed 15 May 2015).

4. Protocol to Eliminate Illicit Trade in Tobacco Products, 2012. Preamble paragraphs 5-7 (https://treaties.un.org/doc/ source/signature/2012/CTC_ix-4-a.pdf, accessed 15 May 2015).

5. Illicit Trade Report 2013. Brussels: World Customs Organization; 2014.

6. Over 3 tonnes of chewing tobacco confiscated in Abu Dhabi raid. The National. 27 January 2015 (http://www.thenational. ae/over-3-tonnes-of-chewing-tobacco-confiscated-in-abudhabi-raid, accessed 23 March 2015).

7. WHOglobal report on trends in prevalence of tobacco smoking 2015. Geneva: World Health Organization; 2015 (http://apps. who.int/iris/bitstream/10665/156262/1/9789241564922_ eng.pdf?ua=1, accessed 15 May 2015).

8. Smokeless tobacco. In: A review of human carcinogens. Part E: Personal habits and indoor combustions/IARC Working Group on the Evaluation of Carcinogenic Risks to Humans. Lyon: International Agency for Research on Cancer; 2009: 274-275 (IARC monographs on the evaluation of carcinogenic risks to humans). (http://monographs.iarc.fr/ENG/Monographs/vol100E/mono100E-8.pdf, accessed 15 May 2015).

9. Heydari G, Tafti SF, Telischi F, Joossens L, Hosseini M, Masjedi $M$, et al. Prevalence of smuggled and foreign cigarette use in Tehran, 2009. Tob Control. 2010;19:380-382.

10. Euromonitor International. Passport Tobacco Global. May 2014 (http://www.euromonitor.com/passport-tobaccoglobal/passport-subscription, accessed 15 May 2015). 